\title{
INTERNATIONAL EXPERIENCE OF DECLARING PROPERTY, ASSETS AND PRIVATE INTERESTS
}

\author{
Anna Tytko', Hanna Stepanova²
}

\begin{abstract}
The aim of the article. To analyse the specificities of asset and private interest declaration by public officials and representatives of political power, as well as to suggest the author's original differentiation of declarations of assets, income, private interests, and gifts. The subject of the study is the procedure for submitting declarations by persons entrusted with functions of the state and local self-government bodies in some countries of Western Europe. Methodology. In the article, the method of deduction and induction enabled to study the features of violating the requirements of financial control through the procedure for submitting a declaration by persons entrusted with functions of the state and local authorities. The methods of deduction and synthesis enabled to define the concept of "asset and interest declaration", practiced in some countries of Western Europe. A comparative legal analysis enabled to study the procedure for submitting an income and expenditure declaration in some Western European countries, identifying the main types of conflict of interest and income declarations, as well as differentiating persons obliged to submit declarations. The results of the study revealed that the foreign experience of asset declaration is closely intertwined with the private interest declaration. Practical implications. In the study: first, the specificities of foreign declaration practice, according to the subjects of such declaration submission, are outlined; second, the procedures for submitting declarations of income and expenditures, as well as interests, are analysed and compared; third, the author's perspective on the differentiation of declarations and declarants is substantiated. Relevance/originality. The comparative legal analysis enabled to study the procedure for submitting a declaration of public officials in some countries of Western Europe, empowering to form perspective areas of legislation development in this sphere.
\end{abstract}

Key words: declaration, private interest, property and assets, conflict of interest, public official, financial control, gift.

JEL Classification: G18, H53, 015

\section{Introduction}

In most European countries, an income and expenditure declaration is considered as a mechanism of effective financial control and as a means of preventing corruption offenses. Nowadays, since corruption offenses grow intensively in the financial and economic sphere, corporate corruption strengthens, the number of offenses related to corruption, abuse of public funds increase, the tendencies of nepotism and cronyism in the system of the state budget distribution strengthen, the issue of improving the declaration procedure is very relevant. The corruption offenses and offenses related to corruption were studied by scholars, such as V. B. Averianov, Yu. P. Bytiak, M. Yu. Bezdolnyi, O. I. Butovych, O. Yu. Drozd, O. V. Klok, V. K. Kolpakov, A. T. Komziuk, M. I. Melnyk, V. Kiselechnyk, V. Ya. Nastiuk, S. S. Rohulskyi, M. Stefanchuk, M. I. Khavroniuk, T. V. Khabarovova, and others.

Therefore, the interrogation of income, asset, and private interest declaration in some countries of

Corresponding author:

${ }^{1}$ National Academy of Internal Affairs of Ukraine, Ukraine.

${ }^{2}$ National Academy of Internal Affairs of Ukraine, Ukraine.
Western Europe, as well as differentiation of the subjects responsible for the declaration, becomes relevant and is considered in this paper. For the successful achievement of these aims, the following tasks should be carried out: 1) to consider submitting declarations by persons entrusted with functions of the state and local selfgovernment bodies practiced in some Western European countries; 2) to differentiate specificities of submitting declarations of a conflict of interest and declarations of income; 3 ) to determine the procedure for submitting a declaration in the financial control system; 4) to carry out a comparative analysis of the procedure for declaring assets in Ukraine and abroad; 5) to determine the subjects of submitting asset declarations.

\section{Presentation of the main material}

Nowadays, the declaration of assets is a part of the system of financial control since this procedure can be considered as an administrative and legal means of preventing corruption. Foreign experience shows that 
a declaration can include not only the obligation to declare incomes and expenditures but also the fixing of personal and family members' private interests.

Therefore, an unresolved issue is the declaration of income, expenditures, property, other assets, financial obligations of the declarant's family members.

Abuse of official position and excess of authority by public officials causes deepening of illicit enrichment, furthermore, discredits the apparatus of state power and spreads corruption offenses in society. From year to year, each state strengthens procedures for financial control over the incomes of public servants, for example, through the procedure for declaration of incomes and assets by high-ranking officials (Prevention of Corruption in the Public Sector in Eastern Europe and Central Asia).

The issue of declaring assets by persons entrusted with functions of the state or local self-government causes constant complications. Due to the changes in the anticorruption strategy, the current legislation changes constantly, giving rise to many problems associated with the late submission of a declaration, therefore, the study of international experience in declaring incomes is relevant. In the countries of Western Europe for a long time, a procedure for declaring assets exists, which is often accompanied by simultaneous declaring private interest.

Legal liability for violating the requirements of financial control contributes to raising the level of responsibility of public officials as persons entrusted with functions of the state and local self-government bodies.

Today, ignorance of the current legislative provisions often leads to legal liability for those who hold responsible and particularly responsible positions, which may adversely affect further career advancement, since persons liable for corruption offenses cannot subsequently enter the public service or hold positions in law enforcement agencies.

The asset declaration system enables to implement a number of tasks that should be resolved through the introduction of a transparent mechanism for demonstrating all financial revenues of public officials, preventing conflicts of interest, investigating cases of illicit enrichment and other unlawful actions by persons performing managerial and administrative functions, moreover, ensuring public confidence in the state apparatus.

Declarations of assets and expenditures are considered as a key tool for preventing a conflict of interest and identifying illicit enrichment. In accordance with Part 5 of Article 8 of the UN Convention against Corruption, each State shall establish measures and systems requiring public officials to make declarations to appropriate authorities regarding, inter alia, their outside activities, employment, investments, assets and substantial gifts or benefits from which a conflict of interest may result with respect to their functions as public officials (Konventsiia Orhanizatsii Obiednanykh Natsii proty koruptsii).

In Europe, two types of such declarations are differentiated:

- general declarations of personal interests and interests of family members or close relatives;

- participants' declaration of any interest they may have in a case pending before a legislative body or an executive authority where they are members.

In most European countries, financial declarations of public officials are defined as "income and asset declarations" or "financial disclosure/asset declarations." The provisions of anticorruption legislation reveal that the purpose of financial declarations is to monitor selectively the lifestyle of the subjects of declaration in order to establish the conformity of their standard of living with the assets and income received by them and their family members in accordance with the declaration of a person entrusted with functions of the state and local self-government bodies.

In each country, the declaration of assets is included in certain areas of regulatory policy of the legislature in different ways.

All existing schemes can be grouped into three main categories, such as the general legislation on the regulation of public service; special legislation on the declaration of income, conflict of interest and on the anti-corruption; special legal regulations.

The main categories of information that requires declaration are movable and immovable property, valuable assets, gifts, debentures, etc., but the point remains about the need to declare travel paid by third parties, especially high percentage $(41 \%)$ of such declaration is in the countries of the Organization for Economic Cooperation and Development with high income (Table 1).

Proper consideration of the asset declaration as one of the main mechanisms for counteracting corruption requires differentiating the main tasks of this system, including preventing conflicts of interest and illicit enrichment. Most European countries combine these two goals in a successful symbiosis by declaring income and expenditure.

Model of asset declaring in order to identify the fact of illicit enrichment aims to reveal the concealment or theft of assets and criminal and administrative liability.

Another model aims to identify a conflict of interest, in particular, situations from which corrupt behaviour may result with respect to the functions of a public official.

Subjects of the declaration are different public officials depending on the duties assigned to them. For example, persons obliged to declare assets are: in Armenia, Bulgaria, France, Norway, Sweden, the members of parliament and government; in Armenia, Bulgaria, France, Kosovo, Portugal, Spain, political officials of a particularly responsible position; all public 
servants in Belarus, Latvia, Poland; special categories such as advisers and officials at state-owned enterprises, in Bosnia and Herzegovina, Ireland, Latvia, Lithuania, Portugal, the United Kingdom; ministers and managers in Albania, Estonia, Ireland (Using Asset Disclosure for Identifying Politically Exposed Persons).

First of all, a declaration consolidates information on personal income, assets, gifts, expenditures, monetary and non-monetary interests. A declaration of income does not necessarily cover all the assets of a person, but only that part, which can directly or indirectly contribute to a conflict of interest or lead to the illicit enrichment of a person.

It is also widespread to include in the declaration and disclose information about the assets of family members of persons who are in the public service (working in the state sector). Family members usually include spouses and minor children.

In countries such as Armenia, Azerbaijan, Belarus, Georgia, Latvia, Moldova, and Ukraine, three types of declarations exist: 1) annual declarations (submitted annually during the performance of the functions of the state and local self-government bodies); 2) a declaration submitted at entering the office; 3) a declaration submitted after release (Yak deklaruiut maino derzhsluzhbovtsiv u riznykh krainakh svitu).

In addition, the financial control system can include other types of declarations, such as a declaration of substantive changes in property status (Macedonia) and so-called exceptional declarations (Albania), where officials file declarations to determine the source of monetary assets from the third parties during the performance of their official duties. International practice differentiates administrative, criminal, civil, and disciplinary liability for violation of the procedure for declaring income.

According to international reports, the procedure for filling in declarations has a number of shortcomings, such as late submission of an income declaration; incompleteness of the information submitted in the declaration; failure to submit a declaration of income; submission of inaccurate information in the declaration; concealment of income or assets (Tilman Hoppe).

Analysis of the experience of declaring assets and private interests enables to distinguish the following types of asset declarations.

The personal income declaration is a financial document for property income, which is not mandatory in France, while in Germany and the UK, members of the parliament are required to declare income, but this does not apply to representatives of local self-government bodies. For example, Members of the British Parliament must declare income if they exceed $£ 59,000$ (Tilman Hoppe).

In Hungary and Italy, members of parliament (in Italy, public servants as well) declare income, while in Poland, representatives of local self-government bodies, as well as politicians and members of parliament, are required to declare their income. In Latvia, both politicians and public servants fill the declarations.

The declaration of family income is also a means of financial control, which indicates the income of family members and relatives. In Poland, the subjects of such declaration are representatives of local self-government and politics. In Hungary, all family members living with politicians and public servants shall declare their income.

The gifts shall be declared in Latvia by all public servants, including representatives of local self-

Table 1

Information categories reflected in the declaration

\begin{tabular}{|l|c|c|c|c|c|c|}
\hline & World & Asia & $\begin{array}{c}\text { Europe and } \\
\text { Central Asia }\end{array}$ & $\begin{array}{c}\text { Latin America and } \\
\text { the Caribbean }\end{array}$ & $\begin{array}{c}\text { Middle East and } \\
\text { North Africa }\end{array}$ & $\begin{array}{c}\text { The high-income } \\
\text { OECD countries }\end{array}$ \\
\hline Real Estate & $\mathbf{8 8 \%}$ & $100 \%$ & $90 \%$ & $100 \%$ & $82 \%$ & $78 \%$ \\
\hline Sources of income & $\mathbf{7 7 \%}$ & $73 \%$ & $95 \%$ & $96 \%$ & $45 \%$ & $100 \%$ \\
\hline Stocks and securities & $\mathbf{8 6 \%}$ & $100 \%$ & $95 \%$ & $100 \%$ & $64 \%$ & $87 \%$ \\
\hline Bank accounts & $\mathbf{8 0} \%$ & $86 \%$ & $86 \%$ & $100 \%$ & $64 \%$ & $72 \%$ \\
\hline Cash (not in accounts) & $\mathbf{2 9} \%$ & $45 \%$ & $38 \%$ & $37 \%$ & $36 \%$ & $16 \%$ \\
\hline Income & $\mathbf{6 7 \%}$ & $73 \%$ & $90 \%$ & $93 \%$ & $27 \%$ & $63 \%$ \\
\hline Movables & $\mathbf{8 0} \%$ & $86 \%$ & $90 \%$ & $100 \%$ & $82 \%$ & $56 \%$ \\
\hline Obligations & $\mathbf{7 2 \%}$ & $82 \%$ & $71 \%$ & $100 \%$ & $45 \%$ & $56 \%$ \\
\hline $\begin{array}{l}\text { Activities prior to work } \\
\text { in the public sector }\end{array}$ & $\mathbf{5 8 \%}$ & $45 \%$ & $71 \%$ & $85 \%$ & $27 \%$ & $75 \%$ \\
\hline Combined managerial posts & $\mathbf{4 1 \%}$ & $45 \%$ & $38 \%$ & $33 \%$ & $27 \%$ & $84 \%$ \\
\hline Gifts & $\mathbf{3 9} \%$ & $59 \%$ & $57 \%$ & $33 \%$ & $9 \%$ & $53 \%$ \\
\hline Other part-time positions & $\mathbf{3 0} \%$ & $32 \%$ & $19 \%$ & $19 \%$ & $36 \%$ & $69 \%$ \\
\hline Unpaid activity & $\mathbf{2 9} \%$ & $18 \%$ & $38 \%$ & $22 \%$ & $9 \%$ & $69 \%$ \\
\hline Expenditures & $\mathbf{1 8} \%$ & $18 \%$ & $38 \%$ & $22 \%$ & $0 \%$ & $25 \%$ \\
\hline Travel paid by third parties & $\mathbf{1 4 \%}$ & $14 \%$ & $5 \%$ & $4 \%$ & $0 \%$ & $41 \%$ \\
\hline $\begin{array}{l}\text { Activity after termination } \\
\text { of work in the public sector }\end{array}$ & $\mathbf{1 4 \%}$ & $0 \%$ & $29 \%$ & $7 \%$ & $0 \%$ & $34 \%$ \\
\hline
\end{tabular}


government bodies and members of parliament. In Poland, this applies only to politicians and elected local officials, in Hungary, to members of parliament. In Germany, Spain, and the United Kingdom, politicians and members of parliament are subject to such declaration. For example, members of the British Parliament must declare gifts, if their value exceeds $1 \%$ of their wages, in Germany, when it exceeds EUR 5,000 , in France, any gift is declared regardless of value (Tilman Hoppe).

A declaration of the private interest related to contractual management is one of the politician's declarations required in Portugal and Spain (includes income information for three years before the appointment and, accordingly, two). In Germany and Spain, this declaration is obligatory for representatives of local self-government bodies.

In the UK, politicians declare the private interest and interests of family members and close associates whenever a reason to believe that the latter may influence their decisions occurs. In France, Hungary, Italy, and Poland, the submission of such a declaration is not obligatory, but in case of an existing conflict of interest, the person is obligated to declare the private interest.

\section{Conclusions}

Declarations of private interests and assets/incomes are often not delimited, so one declaration, as a rule, combines information on private interests and existing property assets.
The most common types of declarations are:

1) A declaration of private interests related to decisionmaking and voting, which is formally a declaration of private interests and is obligatory in countries such as Portugal, Spain, and Germany. In the UK, a public official, a member of parliament and a representative of the local self-government body are required to declare private interests, both their own and ones of family members and close associates, whenever they influence making important decisions in the performance of their duties.

2) An income declaration. This income declaration is not obligatory if any declarations of private interests and assets exist. Commonly, the income declaration applies to politically elected persons and elected local officials.

3) An asset declaration enables to identify and control the conflicts of interest of local elected officials, members of parliament and political parties. This declaration is widespread in Hungary, France, and Spain.

4) An income declaration of the family is established mainly for the declarants, who hold political positions, responsible and especially responsible positions in public authorities.

Specific rules of declaration regulate the procedure for receiving gifts, as the latter can become a prerequisite for illicit enrichment, so the gifts are regulated by strict rules and prohibitions. In European practice, gifts are prohibited if: 1) a gift calls into question a public official's independence and freedom to act; 2) gifts cannot be disclosed for public authorities and citizens; 3 ) the market value of a gift exceeds the established rate.

\section{References:}

Prevention of Corruption in the Public Sector in Eastern Europe and Central Asia. Retrieved from: http://www.oecd.org/corruption/acn/ACN-Prevention-Corruption-Report.pdf

Konventsiia Orhanizatsii Obiednanykh Natsii proty koruptsii [United Nations Convention against Corruption]. (The Law of Ukraine no. 252-V of October 18, 2006). Holos Ukrainy. (in Ukrainian)

Using Asset Disclosure for Identifying Politically Exposed Persons. Retrieved from: http://siteresources.worldbank.org/ EXTFINANCIALSECTOR/Resources/Using_Asset_Disclosure_Identifying_PEPs.pdf

Yak deklaruiut maino derzhsluzhbovtsiv u riznykh krainakh svitu. Chy ye Ukraina osoblyvoiu? [How to declare the property of civil servants in different countries of the world. Is Ukraine special?]. Yevropeiska pravda. Retrieved from: https://www.eurointegration.com.ua/articles/2016/09/26/7054986/

Practitioner manual on processing and analysing income and asset declarations of public officials drafted by Tilman Hoppe, Project Long Term Adviser with in put fromValts Kalniņ̌̌, Council of Europe Expert. (January 2014). Retrieved from: https://rm.coe.int/16806db62d

Practitioner manual on processing and analysing income and asset declarations of public officials drafted by Tilman Hoppe, Project Long Term Adviser with in put fromValts Kalniņš, Council of Europe Expert. (January 2014). 